\title{
PEMBERIAN MAKANAN PENDAMPING ASI DINI MENINGKATKAN RESIKO OBESITAS PADA ANAK
}

\author{
Ismalia Qanit*, Cahaya Carla Bangsawan \\ Fakultas Kedokteran, Universitas Lampung, Jl. Prof. Dr. Ir. Sumantri Brojonegoro No.1, Gedong \\ Meneng, Kec. Rajabasa, Kota Bandar Lampung, Lampung, Indonesia 35145 \\ *ismaliaqanit1@gmail.com (+6281272908548)
}

\begin{abstract}
ABSTRAK
Obesitas merupakan masalah kesehatan dunia yang cukup serius dengan perkiraaan jumlah anak yang mengalami obesitas sebanyak 42 juta. Obesitas diartikan sebagai penumpukan lemak berlebih yang dapat diakibatkan oleh berbagai faktor, salah satunya adalah pemberian makanan pendamping ASI sebelum usia 6 bulan. MP ASI pada anak sebelum usia 6 bulan dapat menyebabkan obesitas karena adanya peningkatan asupan kalori. WHO merekomendasikan pemberian ASI eksklusif selama enam bulan pertama kehidupan untuk "mencapai pertumbuhan, perkembangan, dan kesehatan yang optimalsalah satu faktor penghambat pemberian ASI eksklusif adalah pemberian makanan pendamping ASI terlalu dini. Jenis dan jumlah makanan yang tidak sesuai dengan waktu pemberian selama masa bayi meningkatkan risiko obesitas dalam kehidupan. ).Penelitian yang dilakukan pada 847 anak-anak prasekolah menjelaskan bahwa di antara anak-anak yang tidak pernah disusui atau disusui kurang dari 4 bulan, dengan engenalan makanan pendamping sebelum usia 4 bulan dikaitkan dengan peningkatan enam kali lipat kemungkinan obesitas pada usia 3 tahun. pengenalan makanan padat atau makanan pendamping ASI untuk anak sebelum 6 bulan dikaitkan dengan peningkatan resiko obesitas atau kelebihan berat badan karena diketahui dapat mengakibatkan peningkatan endapan lemak sehingga meningkatkan resiko obesitas di kemudian hari
\end{abstract}

Kata kunci: makanan pendamping ASI, obesitas

\section{EARLY BREASTFEEDING COMPLEMENTARY FOODS INCREASE RISK OF OBESITY IN CHILDREN}

\begin{abstract}
Obesity is a serious global health problem with an estimated 42 million children who are obese. Obesity is defined as the accumulation of excess fat which can be caused by various factors, one of which is complementary feeding before the age of 6 months. MP of ASI in children before the age of 6 months can cause obesity due to an increase in calorie intake. WHO recommends exclusive breastfeeding during the first six months of life to "achieve optimal growth, development, and health. One of the inhibiting factors for exclusive breastfeeding is that complementary feeding is too early. Types and amounts of food that are not in accordance with the time of administration during infancy increase risk of obesity in life.Research conducted on 847 preschoolers explains that among children who have never been breastfed or breastfed for less than 4 months, with the introduction of complementary foods before the age of 4 months is associated with a sixfold increase in the likelihood of obesity at the age of 3 . introduction of solid foods or complementary foods for children before 6 months is associated with an increased risk of obesity or being overweight because it is known to cause an increase in fat deposits thereby increasing the risk of obesity later in life
\end{abstract}

Keywords: complementary feeding, obesity

\section{PENDAHULUAN}

Obesitas yang terjadi pada anak adalah masalah kesehatan yang semakin meningkat prevalensinya di dunia
(Chann dan Jean, 2010).Obesitas pada anak merupakan masalah kesehatan duniayang cukup serius dengan perkiraan jumlah anak usia dibawah 5 
tahun yang mengalami obesitas sekitar 42 juta. Menurut World Health Organization (WHO), obesitas diartikan sebagai akumulasi lemak abnormal atau berlebih yang bisa mengganggu kesehatan (WHO, 2015). Faktor yang berperan pada obesitas sebagian besar adalah interaksi faktor genetik dan faktor lingkungan (Thaker, 2017).Faktor lainnya yaitu sosial ekonomi keluarga yang dapat dilihat dari pendidikan orang tua, penghasilan orang tua, status pekerjaan orang tua dan jumlah anggota keluarga. Status sosial ekonomi mempengaruhi prevalensi terjadinya obesitas pada anak. Faktor lain yang dapat menyebabkan obesitas pada anak adalah pola makan. Pola makan anak harus diperhatikan sejak dini, diketahui bahwa pemberian (Wang dkk. 2017).

Air Susu Ibu (ASI) eksklusif adalah pemberian ASI pada bayi tanpa pemberian cairan atau makanan lain sampai usia bayi mencapai 6 bulan( WHO, 2016).Pemberian ASI eksklusif selama 6 bulan dapat melindungi bayi dari berbagai penyakit, hal ini dikarenakan adanya antibodi yang terkandung didalam kolostrum. Selain itu, ASI juga dapat mencegah terjadinya obesitas pada anak karena ASI dapat mengatur asupan energi berhubungan dengan respon internal dalam menyadari rasa kenyang.

Anak usia 0-6 bulan, hanya memerlukan Air Susu Ibu (ASI) saja sebagai makanan dan minuman utama. Pada tahun 2005, UNICEF dan World Health Organiation (WHO) (dalam Kementerian Kesehatan RI, 2015) merekomendasikan sebaiknya anak hanya disusui Air Susu Ibu (ASI) selama paling sedikit 6 bulan. Makanan padat seharusnya diberikan sesudah anak berumur 6 bulan, dan pemberian ASI dilanjutkan sampai anak berumur dua tahun. Menurut WHO, hanya $40 \%$ bayi di dunia yang mendapatkan ASI eksklusif sedangkan $60 \%$ bayi lainnya ternyata telah mendapatkan Makanan Pendamping Air Susu Ibu (MP-ASI) saat usianya kurang dari 6 bulan. Resiko obesitas di kemudian hari akan lebih tinggi akibat pemberian makanan padat terlalu dini (WHO, 2011 ;Hajrah, 2016). Penelitian ini bertujuan untuk mengatahui faktor resiko pemberian makanan pendamping ASI dini melalui literatur review.

\section{METODE}

Penulisan ini menggunakan studi arikel review. Sumber pustaka yang digunakan dalam menyusun literatur ini menggunakan buku pedoman dan penelitian-penelitian terbaru yang didapat melalui proses literature searching terkait hubungan antara kejadian obesitas dengan pemberian MP ASI dini. Tahun penerbitan artikel yang digunakan adalah antara tahun 20142019. Jumlah sumber yang digunakan dalam penulisan jurnal ini adalah sebanyak 24 sumber.

\section{HASIL}

Hasil penelitian yang dilakukan dapat dilihat bahwa di Kelurahan Bagan Barat memiliki persentase bayi yang diberikan MP-ASI $<6$ bulan $(45,0 \%)$ berstatus gizi tidak normal lebih banyak dibandingkan dengan bayi yang diberikan MP-ASI $\geq 6$ bulan $(11,1 \%)$. Ada hubungan antara pemberian MPASI dini dengan status gizi bayi. Analisis keeratan hubungan kedua variabel adalah bayi yang diberi MPASI < 6 bulan mempunyai peluang status gizi tidak normal 6,545 kali dibandingkan dengan bayi yang diberikan MP-ASI $\geq 6$ bulan (Septiani, 2014). Penelitian yang dilakukan pada 
847 anak-anak prasekolah menjelaskan bahwa di antara anak-anak yang tidak pernah disusui atau disusui kurang dari 4 bulan, dengan pengenalan makanan pendamping sebelum usia 4 bulan dikaitkan dengan peningkatan enam kali lipat kemungkinan obesitas pada usia 3 tahun (Scledar dan Milosevic, 2016).

Pada penelitian yang dilakukan untuk mengetahui hubungan antara pemberian MP-ASI dini dengan kejadian gizi lebih pada bayi, Penelitian ini dilakukan dengan menggunakan metode penelitian kuantitatif analitik dengan desain studi penampang analitik (analytic crosssectional Study) didapatkan sampel sebanyak 67 sampel. Responden Penelitian ini adalah ibu bayi atau anggota keluarga yang dapat memberikan keterangan yang akurat tentang subjek dan hal-hal yang berkaitan dengan aktivitas keluarga dalam gizi dalam. Pengetahuan Ibu diukur dengan cara melakukan wawancara dengan kategori baik apabila responden dapat menjawab 1220 pertanyaan ( $260 \%$ ) dan kategori kurang apabila responden dapat menjawab $<12$ pertanyaan $(<60 \%)$.

Penelitian ini menggunakan sistem Propotional Random Sampling dengan memperhitungkan proporsi atau jumlah populasi bayi $0-11$ bulan pada wilayah Kelurahan Bagan Barat yang diukur berdasarkan Berat Badan dibagi dengan Panjang Badan (BB/PB). Dari hasil penelitian yang dilakukan dapat dilihat bahwa di Kelurahan Bagan Barat memiliki persentase bayi yang diberikan MP-ASI < 6 bulan $(45,0 \%)$ berstatus gizi tidak normal lebih banyak dibandingkan dengan bayi yang diberikan MP-ASI $\geq 6$ bulan $(11,1 \%)$ status gizi tidak normal didominasi dengan obesitas, dengan $\mathrm{p}=0,008$ (Septiani, 2014).
Penelitian lain yang dilakukan pada 302 anak dan pengambilan data dilakukan dengan pengukuran BMI dari BB dan TB. Dari hasil penelitian yang telah dilakukan didapatkan hasil bahwa variabel independen membuat kontribusi signifikan secara statistik yang signifikan untuk model: penggunaan formula tambahan sebelum bulan ketiga (OR $=3,3595 \%$ CI: 1,31 $8,60 ; \mathrm{p}=0,012)$ dan pengenalan makanan tambahan sebelum bulan keenam $(\mathrm{OR}=2,46,95 \% \mathrm{CI}: 1,32-$ 4,58; $\mathrm{p}=0,004)$. Ini menunjukkan bahwa anak-anak yang menggunakan susu formula sebelum bulan ketiga dan pada suplemen sebelum bulan keenam masing-masing 3,35 kali dan 2,46 kali lebih mungkin menjadi kelebihan berat badan / obesitas (Scledar dan Milosevic, 2016).

\section{PEMBAHASAN}

Obesitas yang terjadi pada anak dapat menjadi faktor komorbiditas penyakit lainnya seperti seperti asma, diabetes,dan penyakit kardiovaskuler. Walaupun mekanisme terjadinya belum sepenuhnya di mengerti, tetapi telah dikonfirmasi bahwa obesitas terjadi karena pemasukan energi melebihi pengeluaran energy (Biro dan Wien, 2010). Obesitas diartikan sebagai kelebihan berat badan akibat terjadinya penimbunan lemak berlebih (Kemenkes, 2012). Obesitas dapat disebabkan oleh mutasi pada gen leptin dan reseptornya, serta adanya peningkatan simpanan lemak tubuh (Ganong, 2015 ; Guyton dan Hall, 2013). Status gizi seorang anak dengan obesitas dapat diukur dengan IMT/U. Indeks Masa tubuh merupakan perbandingan antara berat badan anak dalam kilogram dan tinggi anak dalam meter. Obesitas pada anak dapat dipengaruhi oleh beberapa faktor seperti kurangnya aktivitas fisik, 
konsumsi makanan cepat saji, faktor genetic, kurang konsumsi ASI dan pemberian makana pendamping terlalu dini ( Sartika, 2011).

Faktor-faktor penentu risiko awal obesitas adalah (1) percepatan pertumbuhan dan (2) pengembangan preferensi makanan obesogenik. Kebiasaan makan obesogenik mengacu pada konsumsi jangka panjang yang tinggi dari makanan padat energi dan cairan yang pada akhirnya menyebabkan obesitas ( MUniandy dkk, 2016).

Pedoman WHO terus merekomendasikan pemberian ASI eksklusif selama enam bulan pertama kehidupan untuk "mencapai pertumbuhan, perkembangan, dan kesehatan yang optimal." Pedoman pemberian makan bayi yang dirilis oleh Dewan Riset Kesehatan dan Medis Nasional Australia pada tahun 2012 merekomendasikan agar makanan padat diperkenalkan pada "usia sekitar enam bulan"(National Health and Medical Research Council, 2012).Profil kesehatan Indonesia Tahun 2016 menunjukkan bahwa persentase bayi yang telah mendapat ASI eksklusif sampai berusia enam bulan adalah sebesar 29,5\% (Kemenkes, 2015).Hal ini menunjukkan bahwa pelaksanaan pemberian ASI eksklusif masih jauh dari target pemberian ASI eksklusif yakni sebesar $100 \%$, salah satu faktor penghambat pemberian ASI eksklusif adalah pemberian makanan pendamping ASI terlalu dini.

Pemberian makanan pendamping didefinisikan sebagai proses memulai makanan padat dan cairan saat ASI atau jenis susu lainnya sendiri tidak lagi cukup untuk memenuhi kebutuhan gizi bayi. Variasi makanan harus dimasukkan dalam jumlah, frekuensi dan konsistensi yang diperlukan untuk memenuhi kebutuhan gizi bayi (WHO, 2014).

Pemberian ASI ekslusif tanpa makanan pendamping ASI juga dapat mencegah terjadinya obesitas pada anak karena ASI dapat mengatur asupan energi berhubungan dengan respon internal dalam menyadari rasa kenyang. Pemberian ASI juga dapat menyeimbangkan kadar insulin dan hormon leptin pada bayi sehingga dapat mencegah obesitas (Grummer dan Mei, 2004).Sejakusia 6 bulan ASI saja sudah tidak dapat mencukupi kebutuhan energi, protein, zat besi, vitamin $\mathrm{D}$, seng, vitamin A sehingga diperlukan Makanan Pendamping ASI yang dapat melengkapi kekurangan zat gizi makro dan mikro tersebut. Pemberian ASI tetap dianjurkan hingga usia 2 tahun karena dibandingkan dengan susu formula bayi (Hajrah, 2016). Menurut Depkes MP ASI adalah makanan atau minuman yang mengandung zat gizi, diberikan kepada bayi atau anak usia 624 bulan guna memenuhi kebutuhan zat gizi selain ASI (Saputri, 2013).

Makanan Pendamping ASI pertama yang umum diberikan pada bayi di Indonesia adalah pisang dan tepung beras yang dicampur ASI. Kedua bahan makanan tersebut dapat memenuhi kekurangan energi, karena sebuah pisang berukuran $15 \mathrm{~cm}$ dengan berat 80 gram dapat menyumbang $90 \mathrm{kkal}$ dan $28 \mathrm{~g}$ tepung beras menyumbang 102 kkal, Jika mengacu padakebutuhan energi bayi lelaki 6 bulan dengan berat badan $7 \mathrm{~kg}$ dan panjang badan $66 \mathrm{~cm}$, maka kebutuhan energi dari ASI dan MPASI per hari sekitar 770 kkal, dengan perbandingan sekitar $200 \mathrm{kkal}$ dipenuhi oleh MPASI dan sisanya oleh 
ASI (Ikatan Dokter Anak Indonesia, 2015).

WHO Global Strategy for Feeding Infant and Young Children pada tahun 2003 merekomendasikan agar pemberian MPASI memenuhi 4 syarat, yaitu (Ikatan Dokter Anak Indonesia, 2015) (1) Tepat waktu (timely), artinya MPASI harus diberikan saat ASI eksklusif sudah tidak dapat memenuhi kebutuhan nutrisi bayi. (2)Adekuat, artinya MPASI memiliki kandungan energi, protein, dan mikronutrien yang dapat memenuhi kebutuhan makronutrien dan mikronutrien bayi sesuai usianya. (3)Aman, artinya MPASI disiapkan dan disimpan dengan cara cara yang higienis, diberikan menggunakan tangan dan peralatan makan yang bersih. (4)Diberikan dengan cara yang benar (properly fed), artinya MPASI diberikan dengan memperhatikan sinyal rasa lapar dan kenyang seorang anak. Frekuensi makan dan metode pemberian makan harus dapat mendorong anak untuk mengonsumsi makanan secara aktif dalam jumlah yang cukup menggunakan tangan, sendok, atau makan sendiri (disesuaikan dengan usia dan tahap perkembangan seorang anak).

Prinsip - prinsip pemberian MP-ASI menurut Leman adalah sebagai berikut (Hajrah, 2016) (1)ASI eksklusif diberikan sejak lahir sampai 6 bulan, selanjutnya MP-ASI ditambahkan mulai dari usia bayi 6 bulan, sementara ASI diteruskan sampai usia bayi mencapai 2 tahun. (2)Perilaku hidup bersih dan higienis harus diterapkan. (3)MP-ASI dimulai pada usia bayi 6 bulan dengan jumlah sedikit, bertahap dinaikkan sesuai usia bayi, sementara ASI tetap diberikan. (4)Konsistensi dan variasi MP-ASI diberikan secara bertahap, sesuai kebutuhan dan kemampuan bayi.
(5)Frekuensi pemberian MP - ASI semakin sering seiring sejalan bertambahnya usia. (6)MP-ASI yang digunakan dengan komposisi yang diperkaya vitamin-mineral atau berikan preparat vitamin - mineral bila perlu. (7)MP-ASI yang diberikan mengandung cukup energi, protein, dan mikronutrien.

Kuantitas atau kualitas makanan pendamping dapat mempengaruhi berat badan dan status gizi anak. Jenis dan jumlah makanan yang tidak sesuai dengan waktu pemberian selama masa bayi meningkatkan risiko obesitas dalam kehidupan (Muniandy dkk, 2016). Ketika bayi lebih dini diperkenalkan dengan MP-ASI, maka selanjutnya bisa jadi bayi memiliki pola makan yang tidak sesuai dengan tubuhnya kebutuhan energinya. Bayi akan terbiasa dengan makan banyak atau berlebihan. Inilah yang membuat bayi berisiko menjadi gemuk atau obesitas. Mekanisme mengenai obesitas karena pemberian MP ASI dapat terjadi karena karena peningkatan asupan kalori dan protein dari makanan pendamping yang dapat menyebabkan terjadinya peningkatan berat badan dan persentase lemak dalam tubuh anak. Pemberian MP ASI dini dapat menyebabkan terjadinya premature termination of breastfeeding (Hajrah, 2016; Wang dkk, 2017).

Mekanisme biologis yang mendasari efek perlindungan dari menyusui didasarkan pada respons metabolik terhadap ASI dan komposisinya yang unik. Bayi yang disusui memiliki kadar insulin plasma yang lebih rendah, mencegah perkembangan adiposit awal yang berlebihan dan mengurangi penyimpanan lemak(Scledar dan Milosevic, 2016).Salah satu pakar kesehatan mengatakan bahwa pengenalan makanan padat atau 
makanan pendamping ASI untuk anak sebelum 6 bulan dikaitkan dengan peningkatan resiko obesitas atau kelebihan berat badan karena diketahui dapat mengakibatkan peningkatan endapan lemak sehingga meningkatkan resiko obesitas di kemudian hari (Symon dkk, 2017).

\section{SIMPULAN}

Pemberian makanan pendamping ASI dini, sebelum usia anak 6 bulan dapat meningkatkan resiko obesitas pada anak.

\section{DAFTAR PUSTAKA}

Biro FM \& Wien M.2010.Childhood obesity and adult morbidities. Am J Clin Nutr.; 91: 1499-1505. [disitasi tanggal: 17 November 2019]. Tersedia dari: https://www.ncbi.nlm.nih.gov/pub $\underline{\mathrm{med} / 20335542}$

Chan R, Jean W. 2010. Prevention of Overweight an Obesity: How Effective is the Current Public Health Approach. International Journal of Environmental Research and Public Health, 7(3), 765-783 [disitasi tangga; 15 November 2019]. Tersedia dari: https://www.ncbi.nlm.nih.gov/pm c/articles/PMC2872299/

Ganong, W.F. 2015. Buku Ajar Fisiologi Kedokteran Edisi 24. Penerbit Buku Kedokteran EGC: Jakarta.

Guyton, A.C dan Hall, J.E. 2013. Buku Ajar Fisiologi Kedokteran Edisi 12. Elsevier Saunders: Philadelpia

Hajrah. 2016. Gambaran Pengetahuan dan Sikap Ibu Tentang Pemberian Makanan Pendamping ASI (MPASI) Dini di RB Mattiro Baji Kabupaten Gowa Tahun 2016.
[Skripsi]: Universitas Islam Negeri Aliudin. Makasar, [disitasi tanggal : 16 November 2019). Diakses dari: http://repositori.uinalauddin.ac.id/4114/

Ikatan Dokter Anak Indonesia. 2015. Rekomendasi Praktik Pemberian Makan Berbasis Bukti pada Bayi dan Batita di Indonesia untuk Mencegah Malnutrisi. Unit Kerja Koordinasi Nutrisi dan Penyakit Metabolik.

Kemenkes. 2012. Pedoman Pencegahan dan Penanggulangan Kegemukan dan Obesitas Pada Anak Sekolah. Jakarta: Kemenkes.

Kementerian Kesehatan Republik Indonesia. 2015. Pusat Data dan Informasi Situasi dan Analisis Gizi. Kementerian Kesehatan RI : Jakarta Selatan

WHO. 2014 Complementary feeding for breastfed children. WHO

Grummer L, Mei Z. Does Breastfeeding Protect Against Pediatric Overweight? Analysis of Longitudinal Data From the Center for Disease Control an Prevention Pediatric Nutrition Surveillance System. American Academy of Pediatrics. 2004;113 [disitasi tanggal; 15 November 2019]. Tersedia dari: https://www.ncbi.nlm.nih.gov/pub $\underline{\mathrm{med} / 14754976}$

Maharsiwi A. (2014) Hubungan Antara Pemberian MP-ASI DINI Dengan Kejadian Gizi Lebih Pada Bayi Usia 6-24 Bulan Di Wilayah Kerja PUSKESMAS Kartasura, Sukoharjo. [Skripsi]. Universitas Muhammadiyah Surakarta. [disitasi tanggal: 15 November 
2019]. Tersedia dari: http://eprints.ums.ac.id/31110/

Muniandy N, Allotey P, Soyiri I, Reidpath $\quad$ D. 2016. Complementary feeding and the early origins of obesity risk: a study protocol. BMJ Open; 6(11) [disitasi tanggal; 18 November 2019]. Tersedia dari: https://bmjopen.bmj.com/content/ $\underline{6 / 11 / \mathrm{e} 011635}$

National Health and Medical Research Council, Australia. 2012. Infant Feeding Guidelines. National Health and Medical Research Council: Canberra [diditasi tanggal: 14 November 2019]. Tersedia dari: https://www.nhmrc.gov.au/aboutus/publications/infant-feedingguidelines-information-healthworkers

Saputri, K. 2013. Alasan Ibu Memberikan Makanan Pendamping ASI (MP-ASI) Dini dengan Pendekatan Teori Health Belief Model di Wilayah Kerja Puskesmas Kecamatan Pesanggrahan Jakarta Selatan Tahun 2013. [Skripsi]. UIN Syarif Hidayataullah. Jakarta [disitasi tanggal: 19 November 2019]. Tersedia dari: http://repository.uinjkt.ac.id/dspac e/bitstream/123456789/26510/1/K IKI\%20CHAIRANI\%20SAPUTR I-FKIK.pdf

Sartika R. 2011. Faktor Risiko Obesitas Pada Anak 5-15 Tahun di Indonesia. Makara Kesehatan: 15(1); 37-43. [disitasi tanggal: 15 November 2019]. Tersedia dari: http://journal.ui.ac.id/index.php/h ealth/article/download/796/758
Scledar M, Milosevic M. 2016. Breastfeeding and Time of Complementary Food Introduction as Predictors of Obesity in Children. Cent Eur J Public Health: 23(1); 26-31 [disitasi tanggal: 16 November 2019]. Tersedia dari: https://www.ncbi.nlm.nih.gov/pub $\underline{\mathrm{med} / 26036095}$

Septiani W. 2014. Hubungan Pemberian Makanan Pendamping Asi Dini dengan Status Gizi Bayi 0-11 Bulan di Puskesmas Bangko Rokan Hilir. Jurnal /Kesehatan Komunitas;2:4. [disitasi tanggal: 24 Januari 2019]. Tersedia dari: http://jurnal.htp.ac.id/index.php/k eskom/article/download/63/50/

Symon B, Chricton G, Muhlhausler B. 2017. Does the early introduction of solids promote obesity?. Singapore Med J; 58(11): 626631 [disitasi tanggal: 16 November 2019]. Tersedia dari: https://www.ncbi.nlm.nih.gov/pm c/articles/PMC5691224/

Thaker V. 2017. Genetic and Epigenetic Causes of Obesity. Adolesc Med State Art Rev; 28(2): 379-405 [disitasi tanggal : 15 November 2019]. Tersedia dari : https://www.ncbi.nlm.nih.gov/pm c/articles/PMC6226269/

World Health Organization. 2015. Obesity and Overweight (Report). WHO MediaCentre.

Wang Y, Min J, Khuri J, Li M. 2017. A Systemic Examination of the Association between Parental and Child Obesity across Countries. Adv. Nutr; 8(3):436-448 [disitasi tanggal : 17 November 2019]. Tersedia dari 
Jurnal Penelitian Perawat Profesional, Volume 2 No 1 Hal 91 - 98, Februari 2020

Global Health Science Group

https://www.ncbi.nlm.nih.gov/pub $\underline{\mathrm{med} / 28507009}$

WHO. 2016. The World Health Organization's Infant Feeding Recommendation. World Health Organization.
WHO. 2011. The World Health Organization's Infant Feeding Recommendation. World Health Organization. 